\title{
Implementasi Mind Mapping Melalui Project Based Learning Untuk Meningkatkan Kemampuan Berpikir Kritis Dan Hasil Belajar
}

\section{MIND MAPPING IMPLEMENTATION THROUGH PROJECT BASED LEARNING TO IMPROVE CRITICAL THINGKING ABLILITY AND LEARNING OUTCOMES}

\author{
Fendy Hardian Permana*, Dwi Setyawan \\ Program Studi Pendidikan Biologi, Fakultas FKIP Universitas Muhammadiyah Malang, Indonesia \\ *Email: fendy@umm.ac.id
}

Diterima: 09 Februari 2019. Disetujui: 4 Maret 2019. Dipublikasikan: 31 Maret 2019

\begin{abstract}
Abstrak: Penelitian ini bertujuan untuk mengetahui bagaimana implementasi mind mapping melalui project based learning dapat meningkatkan kemampuan berpikir kritis dan hasil belajar. Jenis penelitian ini adalah penelitian tindakan kelas. Penelitian ini dilakukan pada mahasiswa S1 program studi pendidikan biologi FKIP Universitas Muhammadiyah Malang, tepatnya matakuliah yang digunakan adalah mata kuliah telaah kurikulum. Metode penelitian dilakukan melalui 2 siklus, dimana setiap siklusnyua terdapat tindakan perencanaan, pemerapan, observasi, dan refleksi. Hasil penelitian didapatkan terjadinya peningkatan kemampuan dari siklus I ke siklus II yaitu sebanyak 18 mahasiswa pada kemampuan berpikir kritis dan sebanyak 33 mahasiswa pada hasil belajar. Hasil penelitian menunjukkan bahwa terdapat pengaruh penggunaan mind mapping melalui project based learning untuk meningkatkan kemampuan berpikir kritis dan hasil belajar.
\end{abstract}

Kata Kunci : Mind mapping, Project based learning, berpikir kritis, hasil belajar

\begin{abstract}
This study aims to find out how mind mapping implementation through project based learning can improve critical thinking skills and learning outcomes. This type of research is classroom action research. This research was conducted on bachelor students of the Biology Education University of Muhammadiyah Malang, precisely the subjects used were the constitutional court examining the curriculum. The research method is carried out through 2 cycles, where each cycle includes actions, planning, observing, and reflecting. The results showed an increase in ability from cycle I to cycle II as many as 18 students in critical thinking skills and as many as 33 students on learning outcomes. The results showed that there was an effect of using mind mapping through project based learning to improve critical thinking skills and learning outcomes.
\end{abstract}

Keywords : Mind mapping, Project Based Learning, critical thingking, learning outcomes

\section{PENDAHULUAN}

Perkembangan IPTEKS saat ini berkembang dengan pesatnya sehingga mempengaruhi tatanan kehidupan manusia. Perkembangan IPTEKS saat ini memunculkan era revolusi industri 4.0. Era tersebut menuntut manusia untuk memiliki banyak kompetensi, salah satunya adalah berpikir kritis. Pendidikan salah satu aspek yang mendapatkan pengaruh dari perkembangan IPTEKS dan era revolusi industri 4.0 tersebut.

Pengaruh terhadap pendidikan tersebut tentunya akan berpengaruh pada adanya peningkatan-peningkatan program pendidikan di sekolah. Peningkatan yang dapat dilakukan salah satunya adalah melalui proses pembelajaran. Proses pembelajaran yang harus dioptimalkan tentunya adalah pembelajaran yang dapat mengembangkan kemampuan berpikir kritis peserta didik dimana kompetensi tersebut adalah salah satu kompetensi yang dibutuhkan di era saat ini.

Hasil observasi dan penilaian terhadap mahasiswa S1 program studi pendidikan biologi
FKIP UMM pada MK Telaah Kurikulum tahun ajaran 2017/2018 menunjukkan bahwa sebagian besar mahasiswa belum memiliki kompetensi dalam berpikir kritis. Berdasarkan hasil wawancara hal tersebut terjadi pada mahasiswa karena mahasiswa dalam kegiatan perkuliahan belum mendapatkan kegiatan proses pembelajaran yang mengoptimalkan kemampuan berpikir kritis mereka. Temuan tersebut menjadi sebuah permasalahan penting yang harus diselesaikan guna memberikan kompetensi berpikir kritis pada mahasiswa dalam menunjang kehidupan menghadapi era revolusi industri 4.0.

Permasalahan tersebut dapat diselesaikan tentunya salah satunya dengan menggunakan kegiatan proses pembelajaran yang dapat mengembangkan kemampuan berpikir kritis \& hasil belajar mahasiswa. Kemampuan berpikir kritis adalah suatu pikiran reflektif yang difokuskan dalam memutuskan apa yang diyakini untuk dilakukan. Berpikir kritis adalah dimana seseorang bisa menganalisa asumsi-asumsi ataupun pendapat yang melandasinya secara logis agar bisa memilah 
manakah informasi yang harus diambil sebagai informasi yang benar, tidak hanya itu seseorang harus bisa meyakinkan pendapatnya kepada orang lain [1-7]. Berdasarkan hal tersebut maka kegiatan pembelajaran yang dapat mengembangkan kemampuan berpikir kritis adalah metode mind map dan model project based learning.

Model mind mapping adalah suatu kegiatan mencatat konsep materi dalam bentuk peta pikiran, dimana dalam kegiatan mind mapping ini bekerjanya menggunakan dua belah otak (otak kiri dan kanan). Mind mapping yang baik adalah yang menghubungkan warna, symbol, gambar, garis dan kata dari pada memahami peta pemikiran materi [813]. Hasil penelitian dengan tema penelitian pengaruh mind mapping terhadap hasil belajar [14] dan hasil penelitian dengan tema pembelajaran quantum learning dengan menggunakan mind mapping untuk meningkatkan kemampuan berpikir kritis menunjukkan bahwa ada pengaruh antara mind map dengan berpikir kritis dan hasil belajar [15].

Model project based learning adalah pembelajaran yang menggunakan permasalahan lingkungan dalam menkonstruk pengetahuan dan keterampilan hingga menghasilkan produk. Project based learning adalah pembelajaran kontekstual yang mengutamakan student centered dan menggunakan permasalahan lingkungan dalam mengintruksi pengetahuan dan keterampilan belajar siswa [16]. Hasil penelitian dengan tema penelitian pengaruh project based learning terhadap motivasi belajar, kreativitas, berpikir kritis, dan kognitif siswa serta hasil menunjukkan bahwa ada pengaruh antara project based learning dengan berpikir kritis dan hasil belajar [17]. Berdasarkan hal tersebut apabila metode dan model tersebut digabungkan dalam suatu proses pembelajaran tentunya dapat diharapkan bisa meningkatkan pengembangan kompetensi berpikir kritis dan hasil belajar mahasiswa.

Berdasarkan hal tersebut maka dilakukan penelitian dengan judul implementasi mind map melalui project based learning untuk meningkatkan kemampuan berpikir kritis dan hasil belajar. Tujuan penelitian ini adalah untuk mengetahui implementasi mind map melalui project based learning dalam meningkatkan kemampuan berpikir kritis dan hasil belajar mahasiswa.

\section{METODE PENELITIAN}

Penelitian ini dilakukan di program studi S1 pendidikan biologi FKIP UMM pada mahasiswa matakuliah telaah kurikulum kelas B. Jenis penelitian ini adalah penelitian tindakan kelas (PTK). Penelitian ini melibatkan 1 orang dosen sebagai peneliti utama, 1 orang dosen observer, dan 35 mahasiswa.

Pelaksanaan PTK ini dilakukan dengan siklus prencanaan, pelaksanaan, observasi dan refleksi. Instrumen yang digunakan pada penelitian ini memakai lembar observasi aktivitas mahasiswa, lembar obervasi berpikir kritis, lembar observasi aktivitas guru, soal pretes dan postes. Metode yang digunakan pada penelitian ini adalah menggunakan observasi, tes, dan dokumentasi. Keabsahan data dari penelitian menggunakan teknik triangulasi data. Analisis data yang digunakan adalah kuantitatif dan kualitatif.

Tahap perencanaan adalah tahap melakukan observasi awal dalam mengidentifikasi permasalahan yang ada. Tahap pelaksanaan adalah tahap menerapkan mind mapping melalui project based learning untuk meningkatkan kemampuan berpikir kritis dan hasil belajar. Tahap observasi adalah tahap melakukan penilaian pada hasil berpikir kritis dan hasil belajar mahasiswa. Tahap refleksi adalah melakukan analisis pada proses pembelajaran, kemampuan berpikir kritis dan hasil belajar mahasiswa.

\section{HASIL DAN PEMBAHASAN}

Penelitian PTK ini dilakukan melalui 2 siklus, setiap siklus terdiri dari 1 kali pertemuan. Penelitian ini dilakukan dengan peneliti sebagai guru. Setiap siklus terdapat 4 tahapan yaitu perencanaan, pelaksanaan, observasi, dan refleksi. Pembelajaran pada siklus I membahas materi tentang perkembangan kurikulum di Indonesia dan pembelajaran pada siklus II membahas materi tentang model dan prinsip kurikulum. Proses pembelajaran perkuliahan siklus I dan siklus II menggunakan mind mapping melalui project based learning didapatkan data kemampuan berpikir kritis dan hasil belajar mahasiswa pada masing-masing siklus.

Berdasarkan hasil penelitian pada siklus I dan siklus II untuk kemampuan berpikir kritis mahasiswa, didapatkan perubahan peningkatan kemampuan berpikir kritis mahasiswa dari siklus I ke siklus II. Pada siklus I kemampuan berpikir kritis mahasiswa diperoleh data seperti pada Tabel 1 dan Tabel 2. Pada siklus II kemampuan berpikir kritis mahasiswa diperoleh data seperti pada Tabel 3 dan Tabel 4.

Tabel 1. Distribusi hasil tes kemampuan berpikir kritis siklus I

\begin{tabular}{lccc}
\hline No & Nilai & F & \% \\
\hline 1 & $51-60$ & 17 & 52 \\
2 & $61-70$ & 10 & 30 \\
3 & $71-80$ & 4 & 12 \\
4 & $81-90$ & 2 & 6 \\
5 & $91-100$ & 0 & 0 \\
& Jumlah & 33 & 100 \\
\hline
\end{tabular}


Tabel 2. Hasil peningkatan kemampuan berpikir kritis siklus I

\begin{tabular}{lllll}
\hline No & Ketuntasan & KKM & F & \multicolumn{1}{c}{$\%$} \\
\hline 1 & Tuntas & 70 & 6 & 18 \\
2 & Tidak Tuntas & 70 & 27 & 82 \\
& Jumlah & & 33 & 100 \\
\hline
\end{tabular}

Tabel 3. Distribusi hasil tes kemampuan berpikir kritis siklus II

\begin{tabular}{lccc}
\hline No & Nilai & F & \% \\
\hline 1 & $51-60$ & 4 & 12 \\
2 & $61-70$ & 5 & 16 \\
3 & $71-80$ & 13 & 39 \\
4 & $81-90$ & 7 & 21 \\
5 & $91-100$ & 4 & 12 \\
& Jumlah & 33 & 100 \\
\hline
\end{tabular}

Tabel 4. Hasil peningkatan kemampuan berpikir kritis II

\begin{tabular}{lllll}
\hline No & Ketuntasan & KKM & \multicolumn{1}{c}{ F } & \multicolumn{1}{c}{$\%$} \\
\hline 1 & Tuntas & 70 & 24 & 72 \\
2 & Tidak Tuntas & 70 & 9 & 27 \\
& Jumlah & & 33 & 100 \\
\hline
\end{tabular}

Berdasarkan Tabel 1 dan Tabel 2 dapat diketahui bahwa mahasiswa yang memiliki kemampuan berpikir kritis sebanyak 6 orang dan yang belum memiliki kemampuan berpikir kritis sebanyak 27 orang. Hal tersebut menunjukkan bahwa mahasiswa masih sangat perlu untuk diefektifkan kembali kemampuan berpikir kritisnya dengan pembelajaran mind mapping melalui project based learning. Sehingga data dari temuan siklus I ini digunakan untuk melakukan kegiatan di siklus II.

Berdasarkan Tabel 3 dan 4 dapat diketahui bahwa mahasiswa yang memiliki kemampuan berpikir kritis sebanyak 24 orang dan yang belum memiliki kemampuan berpiki kritis sebanyak 9 orang. Berdasarkan data pada siklus I dan siklus II menunjukkan bahwa terjadi peningkatan kemampuan berpikir kritis mahasiswa dari siklus I ke siklus II. Sebanyak 18 mahasiswa mengalami peningkatan kemampuan berpikir kritis.

Tabel 5. Hasil belajar siklus I

\begin{tabular}{lccc}
\hline No & Nilai & F & \% \\
\hline 1 & $51-60$ & 3 & 10 \\
2 & $61-70$ & 8 & 24 \\
3 & $71-80$ & 12 & 36 \\
4 & $81-90$ & 10 & 30 \\
5 & $91-100$ & 0 & 0 \\
& Jumlah & 33 & 100 \\
\hline
\end{tabular}

Tabel 6. Peningkatan hasil belajar siklus I

\begin{tabular}{lllll}
\hline No & Ketuntasan & KKM & F & \multicolumn{1}{c}{$\%$} \\
\hline 1 & Tuntas & 70 & 22 & 67 \\
2 & Tidak Tuntas & 70 & 11 & 33 \\
& Jumlah & & 33 & 100 \\
\hline
\end{tabular}

Berdasarkan hasil penelitian pada siklus I dan siklus II untuk hasil belajar, didapatkan perubahan peningkatan hasil belajar mahasiswa dari siklus I ke siklus II. Pada siklus I hasil belajar mahasiswa diperoleh data seperti pada Tabel 5 dan Tabel 6. Pada siklus II hasil belajar mahasiswa diperoleh data seperti pada Tabel 7 dan Tabel 8.

Berdasarkan Tabel 5 dan Tabel 6 dapat diketahui bahwa mahasiswa yang hasil belajarnya tuntas sebanyak 22 mahasiswa dan yang hasil belajarnya tidak tuntas sebanyak 11 mahasiswa.

Tabel 7. Hasil belajar siklus II

\begin{tabular}{lccc}
\hline No & Nilai & F & \% \\
\hline 1 & $51-60$ & 0 & 0 \\
2 & $61-70$ & 0 & 0 \\
3 & $71-80$ & 15 & 46 \\
4 & $81-90$ & 12 & 36 \\
5 & $91-100$ & 6 & 18 \\
& Jumlah & 33 & 100 \\
\hline
\end{tabular}

Tabel 8. Peningkatan hasil belajar siklus II

\begin{tabular}{lllll}
\hline No & Ketuntasan & KKM & \multicolumn{1}{c}{ F } & \multicolumn{1}{c}{$\%$} \\
\hline 1 & Tuntas & 70 & 33 & 100 \\
2 & Tidak Tuntas & 70 & 0 & 0 \\
& Jumlah & & 33 & 100 \\
\hline
\end{tabular}

Berdasarkan Tabel 7 dan Tabel 8 dapat diketahui bahwa mahasiswa yang hasil belajarnya tuntas sebanyak 33 mahasiswa dan yang hasil belajarnya tidak tuntas sebanyak 1 mahasiswa. Berdasarkan data pada siklus I dan siklus II menunjukkan bahwa terjadi peningkatan hasil belajar mahasiswa dari siklus I ke siklus II. Sebanyak 11 mahasiswa mengalami peningkatan hasil belajar.

Berdasarkan hasil penelitian tersebut menunjukkan bahwa terjadi perubahan perkembangan kemampuan berpikir kritis dan hasil belajar mahasiswa. Perubahan tersebut menunjukkan bahwa mind mapping melalui project based learning dapat mengembangkan kemampuan berpikir kritis dan hasil belajar mahasiswa semakin baik. Seseorang memiliki kemampuan berpikir kritis dapat dilihat dari beberapa indikator ciri berpikir kritis.

Indikator dalam berpikir kritis antara lain adalah a) merumuskan masalah diantaranya adalah mengenal masalah dan memformulasikan pertanyaan yang mengarah investigasi, b) memberikan argument 
diantaranya adalah argument sesuai dengan kebutuhan, menunjukkan persamaan dan perbedaan, c) melakukan deduksi diantaranya adalah mendeduksi secara logis dan menginterpretasi secara tepat, d) melakukan induksi diantaranya adalah menganalisis data, membuat generalisasi, dan menarik kesimpulan, e) melakukan evaluasi diantaranya adalah mengevaluasi berdasarkan fakta dan memberikan alternative lain, f) mengambil keputusan dan tindakan diantaranya adalah menentukan jalan keluar dan memilih kemungkinan yang akan dilaksanakan [6].

Berpikir kritis adalah kompetensi yang benar-benar dibutuhkan ada dalam diri sumber daya manusia Indonesia. Pemerintah menyadari akan hal tersebut, sehingga dalam pergantian kurikulum yang baru untuk sekolah berbagai kompetensi di masukkan dalam kegiatan pembelajaran untuk membekali keterampilan mahasiswa [18]. Berpikir kritis digalakkan oleh pemerintah dengan melalui penerapan kurikulum K13 untuk sekolah. Penerapan kurikulum K13 tersebut berbasis scientific approach/ berbasis ilmiah, dimana dalam penerapannya kurikulum tersebut mampu mengembangkan keterampian bepikir kritis peserta didik. Kurikulum K13 dapat mewujudkan berpikir kritis karena adanya salah satu metode pembelajaran yaitu project based learning.

Project based learning adalah pembelajaran proyek yang identik dengan pembelajaran berbasis sains. Project based learning dapat dengan fleksibel melintasi disiplin ilmu dalam memecahkan masalah dimana peserta didik, dimana peserta didik diberikan kebebasan dalam bereksplorasi. Pembelajaran tersebut merupakan pembelajaran aktif dengan melibatkan siswa secara mandiri. Kegiatan pembelajaran project based learning akan lebih optimal apabila peserta didik mampung menggunakan kedua sisi belah otaknya. Kegiatan yang salah satunya adalah mampu mengaktivkan kedua kerja belah otak adalah dengan pembelajaran mind mapping.

Mind mapping adalah salah satu aktivitas pembelajaran dimana peserta didik akan mengaktifkan kedua belah bagian otaknya dalam melakukannya. Hasil penelitian ini menunjukkan bahwa pembelajaran dengan memadukan mind mapping melalui project based learning mampu mengembankan kompetensi berpikir kritis dan hasil belajar mahasiswa. Pendidikan adalah suatu hal yang sangat penting, karena dengan pendidikan anak akan diajarkan hal-hal yang lebih baik.

\section{KESIMPULAN}

Pembelajaran mind mapping melalui project based learning dapat efektif meningkatkan kompetensi berpikir kritis dan hasil belajar mahasiswa. Pada kemampuan berpikir kritis terdapat 18 mahasiswa yang mengalami perubahan dan perkembangan. Pada hasil belajar terdapat 32 mahasiswa yang mengalami perubahan dan perkembangan.

\section{DAFTAR PUSTAKA}

[1] Amir, M. F. 2015. Proses berpikir kritis siswa sekolah dasar dalam memecahkan masalah berbentuk soal cerita matematika berdasarkan gaya belajar. Jurnal Math Educator Nusantara, 1(2), 159-170.

[2] Zakrah, Z., Lestari, N., \& Kusmiyati, K. (2015). Pengaruh strategi pembelajaran discovery terhadap kemampuan berpikir kritis siswa pada mata pelajaran IPA kelas VIII di SMPN 3 Gunungsari tahun ajaran 2014/2015. Jurnal pijar MIPA, 10(2).

[3] Aini, Z., Ramdani, A., \& Raksun, A. (2018). Perbedaan Penguasaan Konsep Biologi Dan Kemampuan Berpikir Kritis Siswa Kelas X Pada Penerapan Model Pembelajaran Kooperatif Tipe Group Investigation Dan Guided Inquiry di MAN 1 Praya. Jurnal Pijar Mipa, 13(1), 19-23.

[4] Amijaya, L. S., Ramdani, A., \& Merta, I. W. (2018). Pengaruh Model Pembelajaran Inkuiri Terbimbing terhadap Hasil Belajar dan Kemampuan Berpikir Kritis Peserta Didik. Jurnal Pijar Mipa, 13(2), 94-99.

[5] Susilawati, S., Jamaluddin, J., \& Bachtiar, I. (2017). Pengaruh Model Pembelajaran Berbasis Masalah (Pbm) Berbantuan Multimedia Terhadap Kemampuan Berpikir Kritis Peserta Didik Kelas Vii SMP Negeri 2 Mataram Ditinjau Dari Kemampuan Akademik. Jurnal Pijar Mipa, 12(2), 64-70.

[6] Ishak, M., Jekti, D. S. D., \& Sridana, N. (2017). Pengaruh Penerapan Pendekatan Saintifik Menggunakan Model Pembelajaran Discovery Dan Kooperatif Tipe Stad Terhadap Kemampuan Berpikir Kreatif Peserta Didik SDN 13 Ampenan. Jurnal Pijar Mipa, 12(1).

[7] Rusydi, A. I., Hikmawati, H., \& Kosim, K. (2018). Pengaruh Model Learning Cycle 7E terhadap Kemampuan Berpikir Kritis Peserta Didik. Jurnal Pijar Mipa, 13(2), 124-131.

[8] Maspupah, M., Hidayat, A., \& Latifah, R. (2018). Penerapan model pembelajaran cooperatif integrated reading and composition (CIRC) dengan mind mapping terhadap kemampuan berpikir kritis siswa kelas XI IPA SMAN 1 Bojongsoang pada materi sistem 
ekskresi. Jurnal Program Studi Pendidikan Biologi, 8(1), 34-42.

[9] Ningrum, A. S., Lestari, N., \& Kusmiyati, K. (2018). Perbedaan Hasil Belajar IPA Biologi Menggunakan Model Pembelajaran Kooperatif Tipe Team Assisted Individualization Dengan Tipe Mind Mapping Pada Siswa Kelas VII SMP Negeri 19 Mataram. Jurnal Pijar Mipa, 13(1), 37-44.

[10] Ristiasari, T., Priyono, B., \& Sukaesih, S. (2012). Model pembelajaran problem solving dengan mind mapping terhadap kemampuan berpikir kritis siswa. Journal of Biology Education, 1(3).

[11] Tureni, D. (2014). Penerapan Pendekatan Saintifik Berbasis Mind Mapping Dalam Mata Kuliah Fisiologi Hewan Pada Mahasiswa Pendidikan Biologi Universitas Tadulako. Jurnal Kreatif Tadulako, 17(2).

[12] Sari, E. N., Ridlo, S., \& Utami, N. R. (2016). Pengaruh Model Pembelajaran Discovery Learning Dengan Mind Mapping Terhadap Hasil Belajar Siswa Pada Materi SEL di SMA. Unnes Science Education Journal, 5(3).

[13] Kristaliya, D. (2013). Efektivitas Penggunaan Mind Mapping Dan Concept Map Untuk Pendalaman Materi IPA Biologi Siswa Kelas IX SMP Negeri 2 Banyudono Tahun Ajaran 2012/2013 (Doctoral dissertation, Universitas Muhammadiyah Surakarta).

[14] Murni, I. D. A. M., Dantes, N., \& Lasmawan, I. W. (2014). Pengaruh metode pembelajaran mind mapping terhadap hasil belajar IPS ditinjau dari motivasi berprestasi pada siswa kelas VI SD. PENDASI: Jurnal Pendidikan Dasar Indonesia, 4(1).

[15] Sulistyorini, I. K., Joyoatmojo, S., \& Wardani, D. K. (2018). Implementasi model pembelajaran quantum learning dengan menggunakan metode mind mapping untuk meningkatkan kemampuan berpikir kritis dan hasil belajar peserta didik. BISE: Jurnal Pendidikan Bisnis Dan Ekonomi, 4(2), 1-18.

[16] Hayati, W. I., Utaya, S., \& Astina, I. K. (2016). Efektivitas student worksheet berbasis project based learning dalam menumbuhkan kemampuan berpikir kritis siswa pada materi pelajaran geografi. Jurnal Pendidikan, 1(3), 468-474.

[17] Insyasiska, D., Zubaidah, S., \& Susilo, H. (2015). Pengaruh project based learning terhadap motivasi belajar, kreativitas, kemampuan berpikir kritis, dan kemampuan kognitif siswa pada pembelajaran biologi. Jurnal Pendidikan Biologi, 7(1), 9-21.

[18] Syofyan, H., \& Halim, A. (2016). Penerapan Metode Problem Solving Pada Pembelajaran Ipa Untuk Peningkatan Kemampuan Berpikir Kritis Siswa. In Prosiding Seminar Nasional Multi Disiplin Ilmu \& Call For Papers UNISBANK (SENDI_U) KE-2 Tahun. 